\title{
PERANAN LAKI-LAKI DAN PEREMPUAN DALAM GEREJA
}

\section{ERNIATI MARAMPA'}

Lembaga: IAKN Toraja, Posel: erniatimarampa928@Gmail.com

\section{Abstrak}

Di skriminasi terhadap gender gencar di bicarakan dalam pelayanan di Gereja.Banyak yang menolak adanya pelayanan perempuan dalam Gereja dan dianggap sebagai orang yang kedua dalam kepemimpinan di Gereja.Banyak peraturan dan tata gereja yang menolak keleluasaan kepemimpinan seorang perempuan dalam Gereja. Hal ini dilihat dari kemampuan fisiknya bukan dari kesiapan hatinya. Pengaruh dari pemikiran-pemikiran seperti ini adalah factor teologis, budaya dan praktis. Oleh karena itu penulis menyoroti peranan perempuan dalam pelayanan di Gereja.

Kata Kunci :Peran, Perempuandan laki-laki

Pendahuluan

Allah menciptakan manusia menurut gambar dan rupa-Nya. Diciptakan-Nya manusia laki-laki dan perempuan yang sepadan. Manusia diciptakan berbeda jenis kelamin agar saling membutuhkan dan melengkapi. Tanggung jawab yang di emban antara laki-laki dan perempuan mulai tidak seimbang ketika manusia jatuh kedalam dosa. seharusnya tanggung jawab yang sudah di laksanakan sudah terjadi pemilihan peran. Laki-laki harus bertanggung jawab mengelolah bumi dan mencari nafkah untuk keluarga dan perempuan yang melahirkan dan mengurus anak. kebanyakan orang menganggap bahwa laki-laki lebih kuat dari perempuan dalam segala hal namun kenadati demikian peranan perempuan lebih penting dari laki-laki seperti tokoh: Rahab, Rut, Debora, Ester, Maria, Lidya. Pembebasan kaum perempuan adalah untuk kesetaraan dalam gereja dan masyarakat bukan untuk menggantika laki-laki. Tujuan kaum perempuan adalah untuk mewujudkan kasih, perdamaian, kaedilah dalam kerajaan Allah. Namun pembebasan akan terwujudkan jika kita menginginkannya dan siap untuk berjuang sesama kaum perempun untuk mencapainya. 


\section{Tujuan dan Manfaat}

Agar masyarakat memahami bahwa ternyata dalam jabatan gerejawi laki-laki dan perempuan sangat berperan penting. karena adanya laki-laki dan perempuan dalam jabatan gerejawi bisa saling melengkapi untuk mempertanggung jawabkan setiap pelayanan daam gereja.

Pembahasan

Dalam kehidupan masyarakat sekarang ini banyak orang yang menganggap bahwa perempuan adalah orang yang paling lemah sedangkan laki-laki adalah orang yang kuat dalam segala hal. Di dalam Alkitab mengajarkan bahwa semua orang telah kehilangan kemuliaan Allah dan berdosa. Di dalam HAM (Hak Asasi Manusia) tidak membedakan antara hak asasi laki-laki dan hak asasi perempuan semua di pandang sebagai individu-individu yang hidup dalam suatu kesatuan secara utuh. Semua orang mempunyai hak untuk hidup, hak untuk mengelolah ciptaan Tuhan, hak untuk membangun masa depan yang lebih baik. semua orang adalah penyandang citra Allah. sebagai citra Allah manusia tidak hanya di ciptakan sama sepeti mahklukmahkluk lain namun diciptakan sebuah pribadi yang utuh yang bertanggung jawab kepada Allah. dalam memahami manusia tanpa membeda-bedakan sehingga setiap orang adalah sama. Sebagai ciptaa Tuhan yang paling mulia yang diciptakan menurut gambar dan rupa Allah dituntuk untuk bertanggung jawab kepada sang pencipta. manusia yang diciptakan oleh Allah mempunyai tanggu jawab, wewenang dan kebebasan untuk dilakukan dalam setiap kehidupan karena setiap orang telah diberikan hak yang sama oleh Allah untuk dipergunakan di dalam dunia.

Didalam kehidupan bergereja dikembangkan pola pemikiran dalam mencapai kesejajaran antara laki-laki dan perempuan. Didalam Alkitab khususnya dalam perjajian baru cukup memberi penjelasan persamaan antara laki-laki dan perempuan "agar perempuan tidak disisihkan dan peranan-peranan kepemimpinan tertentu di dalam gereja" yang berarti bahwa laki-laki yang memegang kendali kepemimpinan, seyogiannya tidak membatasi ruang serta peranan perempuan yang memiliki kemampuan menjadi pemimpin dalam gereja. ${ }^{1}$

Jika kita membaca Alkitab khususnya dalam surat-surat Rasul Paulus seakanakan tidak memberi peluang agar kedudukan laki-laki sama dengan perempuan dalam persekutuan jemaat. perbedaan antara laki-laki dan perempuan biasanya

${ }^{1}$ Rannu Sanderan, "JABATAN GEREJAWI DAN PERAN PEREMPUAN DALAM PELAYANAN GEREJA" (n.d.). 
dilihat dalam kejatuhan manusia kedalam dosa. Dalam kesejajaran antara laki-laki dengan perempuan dalam jabatan gerejawi harus di sadari degan melaksanakan prinsip kemitraan. Dalam setiap tugas pelayanan harus di lakukan bersama-sama antara laki-laki dan perempuan. Dasar gereja memperjuangankan kemitrasejajaran antara laki-laki dan perempuan adalah Alkitab. Perempuan sebagai mitra sekerja laki -laki dalam rangka misi Allah dalam dunia adalah salah satu pemahaman yang bermakna teologis. Perempuan dan laki-laki dapat dibedakan secara bilogis namun perbedaan bilogis inilah yang bisa menjadi alasan terus menerus untuk membedakan hal-hal lain. di dalam setiap pelayanan dalam gereja yang paling banyak dan rajn adalah kaum perempuan tetapi di dalam kepengurusan sangat minim. pemikiran yang dimiliki waraga jemaat yang masih membedakan kedudukan antara laki-laki dan perempuan. manusia melanjutkan hidup dengan bekerja. pekerjaan yang dilakukan hanya dimengerti sebagai pengahasil uang saja namun pada dasarnya kegiatan yang dilakukan setiap hari terutama dalam pelayanan sangat bermanfaat. setiap pekerjaan yang dilakukan selalu dikaitkan dengan laki-laki karena setiap pekerjaan yang dikerjakan haruslah orang yang kuat dan berotot dan berani dalam hal ini adalah laki-laki itu adalah salah satu yang membedakan antara perempuan dan laki-laki sehingga masyarakat masih berdominasi kaum laki-laki. Dalam persekutuan gereja yang memperlihatkan perbedaan peranan antara laki-laki dan perempuan kebanyakan orang beranggapan bahwa kepemimpinan di dalam gereja lebih banya di pegang oleh laki-laki dari pada perempuan. Kebanyakan orang beranggapan bahwa perempuan tidak layak sebagai seorang pemimpin yang setara dengan laki-laki dalam memimpin gereja seperti majelis tampaknya tidak ada keseimbangan antara laki-laki dan perempuan. dalam kehidupan praktis dimana kaum perempuan lebih banyak perperan dalam unsur-unsur domestik. perbedaan tersebut mengarah pada pola pengertian yang memandang laki-laki lebih utama dari perempuan kebudayaan banyak mempengaruhu pemahaman warga jemaat untuk membedaka antara laki-laki dengan perempuan. manusia sejak lahir sudah dibentuk dalam proses sosialisasi kemanusiaan. Didalam proses sosialisasi menuju proses akulturasi sebagai bagian dari kehidupan manusia sehingga mempengaruhi pola hidup dan tingkah laku manusia di tengah-tengah kehidupan bersama. Perilaku manusia lebih banyak berfungsi karena dibentuk oleh pengamatan dan dipengaruhi oleh proses meniru perlaku orang lain Dalam lingkungan masyrakat yang baik memegang teguh nilai-nilai dan norma-norma perilaku yang biak sejatinya dapat 
menyokong kehidupan keluarga kristen yang tinggal dalam suatu lingkungan secara baik. beberapa orang menyakan faktor-faktor apa saja yang yang memberi pengaruh kuat bagi pertumbuhan iman kebnyakan dari mereka menyebut nama guru, pendeta, pemimpin pemuda dan pemimpin-pemimpin lainya. ${ }^{2}$

Kesimpulan

Faktor yang mempengaruhi perbedaan peranan antara laki-laki dan perempuan dalam pelayanan jemaat Didalam Alkitab jemaat belum memadai tentang perempuan dan laki-laki

alasan praktis berpengaruh terhadap perbedaan peranan laki-laki dan perempuan dalam pelayanan jemaat. perempuan di anggap lemah dalam pelayanan tidak rasional dan bergantung terhadap laki-laki sebaliknya laki-laki dianggap lebuh kuat dalam urusan publik. Tugas dan tanggung jawab setiap orang kristen ialaj memulai dengan sikap baru hakkatnya manusia mempunyai harga diri, harkat dan martabat pemberian Tuhan oleh karena itu tidak seorang pun manusia dapat menguranginya apalagi memanipulasinya. Alkitab menekankan betapa pentingnya disiplin penh kasih.

\footnotetext{
${ }^{2}$ Rannu Sanderan, "EXEMPLARY MENEMUKAN KUNCI PENDIDIKAN IMAN BAGI ANAK DALAM KELUARGA DAN PEMBELAJARAN AGAMA DI SEKOLAH" (n.d.).
} 


\section{DAFTAR PUSTAKA}

Sanderan, Rannu. "EXEMPLARY MENEMUKAN KUNCI PENDIDIKAN IMAN BAGI ANAK DALAM KELUARGA DAN PEMBELAJARAN AGAMA DI SEKOLAH" (n.d.).

Sanderan, Rannu. "JABATAN GEREJAWI DAN PERAN PEREMPUAN DALAM PELAYANAN GEREJA" (n.d.). 